\title{
隠匿情報検査で生起する眼球運動の心理的背景
}

\author{
○小野 洋平 \\ (駒澤大学) \\ キーワード : 隠匿情報検査, 眼球運動, 反応時間 \\ Psychological factors influencing eye movements in Concealed Information Test \\ Yohe i 0 no \\ (Komazawa University) \\ Key Words : concealed information test, eye movements, reaction time
}

隠匿情報検査では主に音声刺激が呈示され，その際の自律 神経系反応から被検査者の事件に関する認識の有無を判定す る。一方，新たな指標として検討されている眼球運動では視 覚刺激を同時呈示し，刺激間の停留が比較される。これまで に非裁決刺激に比べ，裁決刺激に対して停留が少なくなる結 果が得られており, 反応背景の一つに隠蔽意図が挙げられて いる。本研究では, 刺激に対する停留反応を詳細に分析し, 視覚刺激の対呈示法を用いた隠匿情報検査において生起する 眼球運動の心理的背景について検討した。

\section{方 法}

実験参加者 大学生50名（男12名, 女38名 平均年齢 19.3 歳, $S D=0.74)$ 。

実験器具 TalkEye2(竹井機器製)を用いて眼球運動をサンプ リング周波数 $60 \mathrm{~Hz}$ ，分解能 $0.1 \mathrm{deg}$ で非接触的に測定した。 実験刺激 ペン・タバコ・爪きり・スプーン・空の音楽メ ディア

手続き 模擬窃盗課題では5つの物品のうち1つを身に着けて 隠すように教示した。次に，5つの物品画像(視覚刺激)を一覧 呈示し，それぞれの物品を識別できた者に隠匿情報検査を実 施した。検査では，画面中央に注視点を3秒表示したのち，画 面の左上, 左下, 右上, 右下の4位置のいずれか 2 所に視覚 刺激をランダムに3秒間対呈示した。視覚刺激呈示中に「隠匿 された物品があるか」の質問に「いいえ」と返答させた。そ の後, ブランク刺激を 14 秒間呈示した。これを1試行として, 対呈示される視覚刺激に裁決刺激が含まれる試行を4試行, 非 裁決刺激のみの試行を 16 試行, 計 20 試行実施した。なお, 刺 激が呈示される画面の位置および裁決・非裁決試行の呈示順 序は実験参加者ごとにランダムであった。また，本試行に入 る前に，アルファベットを刺激として3試行練習を行い，実験 参加者に手続きを理解させた。

\section{結 果}

本実験では，画面に視覚刺激が呈示されている間の眼球運 動データを分析した。刺激に対する停留は視覚刺激が呈示さ れている領域を取得し，そこに視線が166.7ms以上とどまって いる場合を1回の停留と定義した。また, 視覚刺激が対呈示さ れて最初に刺激に停留した反応を第 1 停留反応とし, 裁決試行 における裁決刺激への第1 停留反応を試行数で割り, 第1 停留 反応率を求めた。次に, 裁決・非裁決試行の第 1 停留反応の反 応時間を視覚刺激間で比較・分析した。

裁決試行における第1 停留反応率は平均 $36.2 \%(S D=0.32)$ で あった。本実験手続きでは2刺激が対呈示されることから, 裁 決刺激に最初に停留する期待確率は50\%である。そこで，母平 均を $50 \%$ として 1 標本のt検定を行った。その結果，裁決刺激の 第1 停留反応率は期待確率よりも有意に低くなっていた

$(t(49)=3.01, p<.01, d=0.42)$ 。

Figure1は, 裁決 · 非裁決試行において非裁決刺激が第1 停 留反応であった場合の反応時間を示したものである。なお，
裁決刺激に対し第1 停留反応が得られなかった実験参加者が多 く, 本研究では非裁決刺激に対する反応時間を試行間で比較 した。また, 裁決試行における第 1 停留反応がすべて裁決刺激 であった参加者を除き分析を行った。

非裁決刺激への第 1 停留反応時間を裁決 · 非裁決試行間で比 較した結果, 裁決試行の反応時間は非裁決試行に比べて有意 に長くなっていた $(t(36)=2.45, p<.05, d=0.40) 。$

$$
\text { 考 察 }
$$

本研究では, 視覚刺激の対呈示による隠匿情報検査におけ る心理的背景を視覚刺激への停留反応とその反応時間から検 討した。裁決刺激への第 1 停留反応率が期待確率に比べて有意 に低かったことから, 視覚刺激が対呈示された際に, 裁決刺 激が含まれるかを判断し, 非裁決刺激に視線を向けて検出を 回避しようと動機づけられると推察される。すなわち, 本研 究のような2刺激を対呈示する刺激呈示法では, 裁決刺激を避 け, 非裁決刺激に対して視線を向けるなど, 実験参加者の隠 蔽意図を反映する行動パターンが観察されると考えられる。

一方, 非裁決刺激に対する第1停留反応時間は試行間で異 なっており, 裁決試行で有意に長くなっていた。この結果に ついては, 視覚的注意や反応統御による認知的負荷から説明 可能であろう。視覚的注意には必ずしも視線の移動を伴わな い場合があり，この考えに立脚するならば，第1停留反応率の 低さは裁決刺激に注意が払われなかったというより，視線移 動なしに裁決刺激に注意が向けられていた可能性があり、そ の結果, 非裁決刺激への視線移動に遅れが生じたと解釈する ことができる。また, 裁決刺激に対する注意を開放し, 裁決 刺激を避けて, もう一方の非裁決刺激に対して視線を向ける 反応統御を行うことによる認知的負荷により, 反応が遅れた 可能性も考えられる。しかしながら, 本研究の手続きでは, 裁決刺激の出現率が他の非裁決刺激よりも低く, レアな刺激 に注意が向けられた可能性も否定できない。そこで今後は刺 激の出現率を等質にし, 改めて隠匿情報検査で生起する眼球 運動の心理的背景について検討することが求められる。

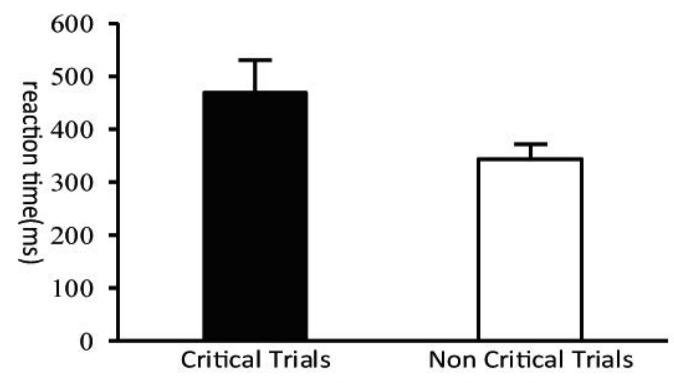

Figure 1. 非裁決刺激に対する第1停留反応時間。 エラーバーは標準誤差を示す。 